ON HUMANISTIC EDUCATION

cran 
This page intentionally left blank 


\title{
Giambattista Vico
}

\author{
ON HUMANISTIC EDUCATION \\ (SIX INAUGURAL ORATIONS, I699-I707)
}

FROM THE DEFINITIVE LATIN TEXT,

INTRODUCTION, AND NOTES

OF GIAN GALEAZZO VISCONTI

cran

Translated by

Giorgio A. Pinton and Arthur W. Shippee

with an Introduction by

Donald Phillip Verene

Cornell University Press

Ithaca and London 


\section{Copyright $\mathbb{C} 1993$ by Cornell University}

All rights reserved. Except for brief quotations in a review, this book, or parts thereof, must not be reproduced in any form without permission in writing from the publisher. For information, address Cornell University Press, Sage House, 512 East State Street, Ithaca, New York $\mathrm{I}_{4} 8 \mathrm{5o}$.

Authorization to base the English translation on the Latin text edited and annotated by Gian Galeazzo Visconti, Le Orazioni Inaugurali, I-VI (Bologna: Il Mulino, 1982), volume 1 of Opere di Giambattista Vico commissioned by the Centro di Studi Vichiani, has been granted by the director of the Centro di Studi Vichiani, Naples, Italy.

The summaries of the Orations are reprinted from The Autobiography of Giambattista Vico, translated by Max Harold Fisch and Thomas Goddard Bergin, copyright 101944 by Cornell University and used by permission of the publisher, Cornell University Press.

First published 1993 by Cornell University Press

ISBN-1 3 : 978-0-8014-28 $38-8$ (cloth : alk. paper)

ISBN-1 3: 978-0-8014-8087-4 (pbk. : alk. paper)

Library of Congress Catalog Card Number 92-56787

Printed in the United States of America

Cornell University Press strives to use environmentally responsible suppliers and materials to the fullest extent possible in the publishing of its books. Such materials include vegetable-based, low-VOC inks and acid-free papers that are recycled, totally chlorine-free, or partly composed of nonwood fibers. For further information, visit our website at www.cornellpress.cornell.edu.

$\begin{array}{lllllllllll}\text { Cloth printing } & \text { Io } & 9 & 8 & 7 & 6 & 5 & 4 & 3 & 2 & 1\end{array}$

Paperback printing $\quad \begin{array}{llllllll}10 & 9 & 8 & 7 & 6 & 5 & 4 & 3\end{array}$ 